\title{
OCA INDEX AS INDICATOR OF THE CZECH REPUBLIC'S PREPAREDNESS TO JOIN THE EUROPEAN MONETARY UNION
}

\section{${ }^{a}$ SARKA HYBLEROVA}

Technical University of Liberec, Faculty of Economics, Department of Finance and Accounting, Studentská 1402/2, 46117 Liberec 1, Czech Republic email: ${ }^{a}$ sarka.hyblerova@tul.cz

The paper is the output of the institutional support that was implemented at the Faculty of Economics of the Technical University in Liberec in 2021.

Abstract: The optimum currency area (OCA) theory evaluates the currency area as optimum at a time when the participating countries are not at risk of macroeconomic instability due to the existence of a common currency. The OCA index is a tool used to comprehensively assess the costs and benefits of a candidate for joining a monetary union. It is constructed as a bilateral index assessing the appropriateness of introducing the single currency in two countries. The article presents the OCA index quantified for the Czech Republic in relation to Germany, which is considered to be the core of the European Monetary Union. Since the OCA index needs to be interpreted in a temporal or spatial comparison, the calculation of the OCA index was also performed for other countries of the Visegrad Group (V4) and furthermore for Austria and Portugal, using data from the period of 2007-2019. The results of the Austria and Portugal, using data from the period of 2007-2019. The results of the OCA index show a high degree of variability in the Czech Republic in the observed period. While in the first half of the period under review, the Czech Republic achieved the best results within the assessed economies and the Czech Republic's level of preparedness for the common currency with Germany was higher than in the case of Austria, it fell sharply after 2012 . The reason can be seen, among other things, in the higher growth rate of the Czech economy than in the euro area. Although the OCA index is an indicator assessing the preparedness of an economy to join a monetary union, it cannot be the only indicator. Other important criteria include, for example, labour mobility, price and wage flexibility, fiscal integration and more. Although the Czech Republic is approaching the euro area average in all key indicators, the gap from it remains significant for most indicators and thus continues to be a factor against the adoption of the euro in the coming years.

Keywords: Optimum currency area, OCA index, monetary integration, European Monetary Union.

\section{Introduction}

A monetary area is an area in which individual countries use a common currency, while not every country is a suitable candidate for membership in a monetary union. The advantage of membership in a monetary union lies in the elimination of transaction costs of exchange and exchange rate risk or an increase in competition and thus making a pressure on the quality of production. The costs then stem mainly from the loss of national monetary policy as a tool for responding to economic shocks and the associated possible losses in economic performance. The economic advantage of membership in a monetary union must therefore be assessed by comparing the benefits and costs associated with the adoption of the single currency. The theory of optimal currency areas (OCA) is used to assess the appropriateness of adopting the single currency. The economic advantage of membership in a monetary union must therefore be assessed by comparing the benefits and costs associated with the adoption of the single currency. The theory of optimal currency areas (OCA) is used to assess the appropriateness of adopting the single currency. The monetary area becomes optimal when the participating countries do not face macroeconomic instability due to the existence of a common currency. This situation arises when the participating countries either have their economic cycle synchronized and are exposed to symmetric demand and supply shocks or are at least equipped with sufficiently flexible adjustment mechanisms in the goods and factor markets. If none of the above conditions of optimality are met, the participating countries risk macroeconomic instability in the form of permanent differences in the level of production and unemployment.

The basis of the so-called classical theory of OCA was laid by Mundell (1961), McKinnon (1963) and Kenen (1969); they thus formulated a completely new approach to convergence assessment. Although the theory of optimal currency areas has had a number of critics since its inception (Mongelli, 2008; Corsetti, 2008, and others), it is considered a comprehensive tool for assessing currency areas.
The basic factors determining the success of the functioning of the monetary union of the classical OCA theory include the mobility of production factors, the openness of economies and the diversification of production. Many authors (Beine, 2000) later use other alternative OCA assessment criteria in their work, such as price and wage flexibility, financial market integration, similarity of inflation rates, fiscal and political integration (Baldwin and Wyplosz, 2019), and others. In the development of OCA theory, Europe has been the main focus of research since the 1990s, due to long-standing efforts to create a monetary union and the availability of a range of data.

\section{Methods of Research}

The OCA theory has identified the above-mentioned basic economic characteristics to be met by cooperating countries in order to determine whether the use of the single currency is optimal. However, these indicators can only be assessed individually. In order to comprehensively assess the achieved degree of convergence, so-called OCA indices were created. These indices allow a comprehensive assessment of the state of convergence on the basis of one dimensionless number, the value of which expresses the suitability or unsuitability of membership in the monetary union for the respective economy. The construction of the OCA index is based on the formulation of a one-equation econometric model using cross-sectional data. All indices are based on a minimization criterion, which means that the lower the absolute value of the index, the more likely the two compared economies form the optimal monetary area and the benefits of adopting the single currency are maximum. The general disadvantage of OCA indices is the absence of critical values that would determine the fulfillment or non-fulfillment of individual criteria.

One of the first OCA indices was published by Bayoumi and Eichengreen (1997a) who examined key factors such as asymmetric output shocks, trade ties, currency usability for transactions, labour mobility, and the range of automatic stabilizers. The OCA index was then published in the form of the following regression equation using indicators of economic cycle alignment (SD $(\Delta y \mathrm{y}-\Delta \mathrm{yj}))$, similarity of economic structure (DISSIM), trade interconnectedness (TRADE) and economic size (SIZE). The SD(eij) indicator indicates the variability of the bilateral exchange rate between countries $\mathrm{i}$ and $\mathrm{j}$.

$$
\begin{aligned}
& S D\left(e_{i j}\right)=\alpha+\beta_{1} \times S D\left(\Delta y_{i}-\Delta y_{j}\right)+\beta_{2} \times D I S S I M_{i j}-\beta_{3} \times \\
& T R A D E_{i j}+\beta_{4} \times S I Z E_{i j}
\end{aligned}
$$

Bayoumi and Eichengreen estimated the parameters of the model based on empirical research as follows:

$$
\begin{aligned}
& S D\left(e_{i j}\right)=-0,09+1,46 \times S D\left(\Delta y_{i}-\Delta y_{j}\right)+0,22 \times \\
& \operatorname{DISSIM}_{i j}-0,054 \times T R A D E_{i j}+0,012 \times S I Z E_{i j}
\end{aligned}
$$

The SD indicator $(\Delta y \mathrm{y} \Delta \mathrm{yj})$ is calculated as the standard deviation of the difference in the logarithm of real output between $\mathrm{i}$ and $\mathrm{j}$. If in both countries the economic cycles are symmetric and the national outputs move together, the resulting value of the indicator is low. The DISSIM indicator is the sum of the absolute differences in the shares of agricultural, mineral, and manufacturing trade in total merchandise trade. A lower value of the DISSIM indicator means better conditions for the adoption of the common currency. The TRADE indicator is the mean of the ratio of bilateral exports to domestic GDP for the two countries. The SIZE indicator measures the size of economies and is the mean of the logarithm of the two GDPs. The lower values of the indicators (with the exception of the TRADE indicator) represent a higher structural convergence between the examined economies. Thus, better conditions for the adoption of the common currency can be expected. 
Data from non-European economies were also used in the construction of the above regression equation (2), therefore some authors (for example Horváth and Komárek, 2002) use its form adapted for European countries, also published by Bayoumi and Eichengreen (1997b), to assess optimal monetary areas in Europe. The modified equation is as follows:

$$
\begin{aligned}
& S D\left(e_{i j}\right)=0,75 \times S D\left(\Delta y_{i}-\Delta y_{j}\right)-0,0026 \times T R A D E_{i j}- \\
& 0,13 \times \operatorname{DISSIM}_{i j}+0,031 \times S I Z E_{i j}
\end{aligned}
$$

Equation (3) was used to calculate the OCA index of the Czech Republic in relation to Germany which is considered to be the core of the European Monetary Union (EMU). Another reason for choosing Germany is the fact that Germany is the largest economy in EMU and carries out foreign trade with all EU countries. Germany is used as a comparison base for the calculation of OCA indices in the works of the authors such as Cincibuch and Vávra (2000), Horváth, Komárek (2003), Pilat (2011), Frydrych (2018), Selvaraj (2020), Akalpler (2021) and others.

Since there is no clear numerical criterion of the OCA index to draw a conclusion about the usefulness or uselessness of the common currency, the OCA index must be interpreted in temporal or spatial comparison. For the purpose of this comparison, the calculation of the OCA index was also performed for other countries of the Visegrád Group (V4) that is Slovakia, Hungary and Poland, as these are the economies of the Central European region to which the Czech Republic belongs. Another economy studied is Austria, partly because it is part of the Central European region and partly because it is part of the so-called EMU core. The last country to be compared is Portugal as a representative of the periphery of the EMU.

The World Bank data, including the World Integrated Trade Solution database, were used for the calculation. These were data on real GDP at 2010 prices in US dollars, nominal GDP at current prices in US dollars, total exports in US dollars and exports of each economic category according to SITC rev2 Groups. Data for the period 2007-2019 were used.

\section{Results of the Research}

When comparing the values of the indicator of the alignment of $\mathrm{SD}(\Delta \mathrm{yi}-\Delta \mathrm{yj})$ economic cycles of individual economies with Germany, it is evident that in the observed period they gradually converged, see Figure 1. While the Czech Republic showed better (lower) results in the first two monitored periods than most other countries under comparison, since 2012 it has shown the highest values, which means the least alignment of the economic cycle with Germany of all countries under comparison. However, it should be pointed out that the differences between individual countries are only minimal in the last monitored period (2014 - 2018). In the long run, Austria shows very low values indicating the highest alignment of the economic cycle with Germany. The long-term stable mutual convergence of Austria and Germany is also confirmed by the Gebauer study (2021). Figure 1 also shows that the alignment of Portugal's economic cycle with that of Germany has been improving for a long time. In the period of 2014 - 2018, Portugal showed the second best result in this area following Austria.
Figure 1 Development of SD values $(\Delta \mathrm{yi}-\Delta \mathrm{yj})$

Development of SD indicator

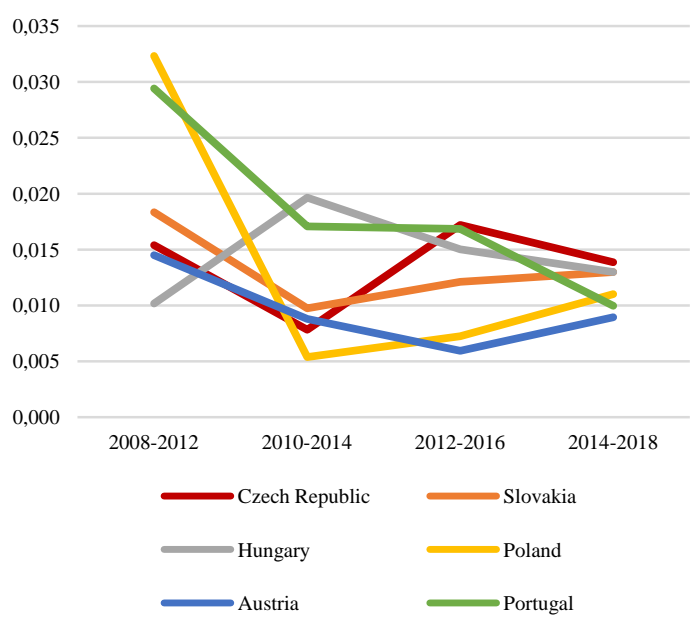

Source: author's own source based on the World Bank data

In the area of the TRADE indicator, which testifies the interconnectedness of trade between the assessed economies and Germany, the Czech Republic has been doing best in the longterm economies analysed; see Figure 2. The TRADE indicator can be assessed positively in relation to higher structural convergence between the economies examined, if it reaches higher values. The Czech Republic reaches values in the range of 0.15 to 0.24 in the monitored period with an increasing trend. By contrast, Portugal shows the least trade interconnection with Germany in this comparison, with values of only between 0.02 and 0.03 .

Figure 2 Development of TRADE indicator values

$$
\text { Development of TRADE indicator values }
$$

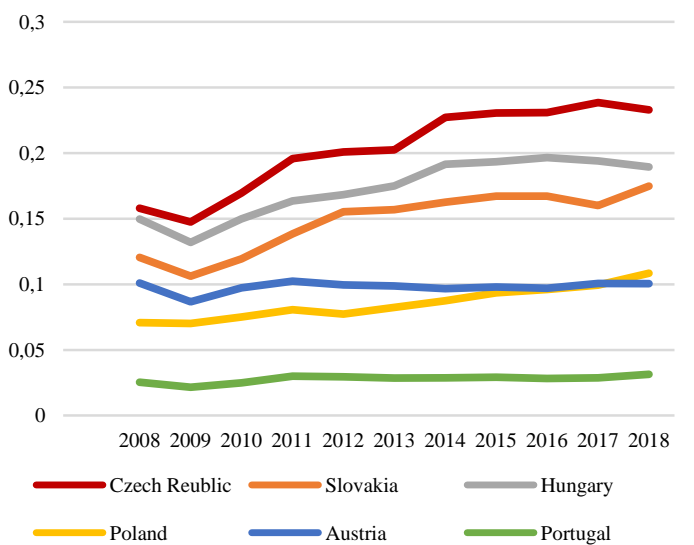

Source: author's own source based on the World Bank data

The result of the Czech Republic in the area of the TRADE indicator is by no means surprising. Germany is the Czech Republic's main trading partner and the Czech Republic is also an important trade partnership for Germany. According to DESTATIS (2021), the Czech Republic is the 11th most important export destination for Germany and the 7th most significant import country. The main areas of mutual trade relations between the two countries are engineering products.

According to Horváth and Komárek (2002), the variables SIZE and DISSIM are not significantly different from zero for the 
evaluation of exchange rate variability; therefore, their results are not presented in more detail here.

The total value of the OCA index is shown in Figure 3 from which it is possible to trace the mutual approximation of the OCA index values of the monitored countries. While in the period of 2008 - 2012 the assessed economies showed index values in the range of $0.015-0.032$, in the period of $2014-2018$ the values ranged from only $0.014-0.017$.

Figure 3 OCA index

OCA Index

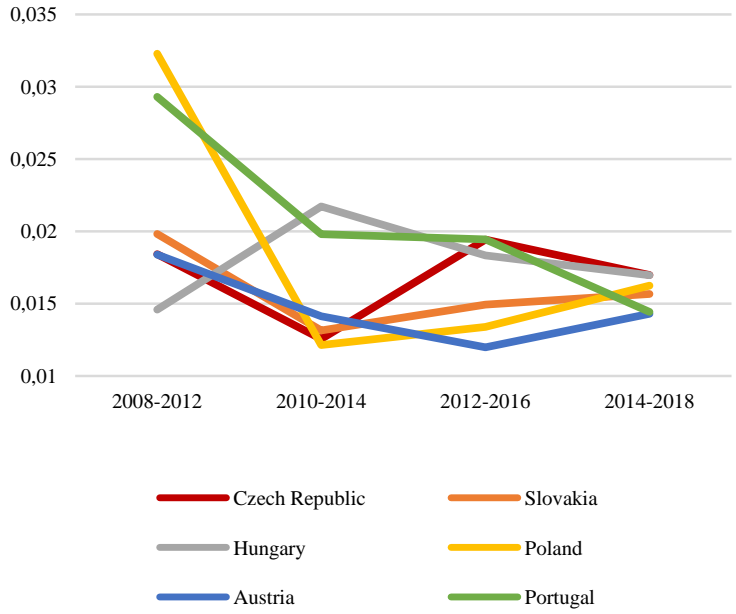

Source: author's own source based on the World Bank data

The results of the OCA index show a high degree of variability in the Czech Republic in the observed period. While in the period of 2010 - 2014, the Czech Republic achieved the best (lowest) values within the monitored economies, in the period 2012 - 2016 these were the worst (highest) values. In the years 2010 - 2014, the level of preparedness of the Czech Republic for the common currency with Germany was thus higher than in the case of Austria, but later decreased significantly. This fluctuation can be partly attributed to the effects of the economic crisis, which occurred later after 2009 and persisted and disrupted the degree of alignment of the economic cycles of the Czech Republic and Germany. The impact of the crisis on the CEE region was particularly strong. Deterioration of the OCA index results can also be observed in Slovakia and Poland in this period. Later, a higher growth rate of the Czech economy than in the euro area had the effect of reducing the Czech Republic's cyclical alignment with Germany. The main reason was the growth of industrial production, which in the Czech Republic has long been above the euro area average. In the last monitored period in the Czech Republic (2014 - 2018), it is possible to observe again a slight improvement in the value of the OCA index and its approximation to the results of other countries.

From the values of the OCA index reported by countries in the last monitored period (2014-2018), it can be concluded that the country's involvement in EMU can contribute to reducing the probability of real asymmetric failures. The countries involved in EMU (especially Austria) show better (lower) values of the OCA index than the countries outside EMU. This statement can be supported, for example, by the finding of Sideris (2011), which concluded, among other things, that a higher degree of structural convergence can be identified in the countries that have adopted the euro. On the other hand, in the case of the Czech Republic's involvement in the EMU, this effect can be estimated as relatively small as the Czech Republic's trade is already largely focused on the euro area and gradual euroization is taking place, see also Mačí (2020).

\section{Discussion}

While very low values of the OCA index indicate the usefulness of the common currency, high values indicate structural differences in economies requiring a change in the exchange rate in the event of asymmetric shocks and thus less advantage in creating a monetary union. However, there is no clear criterion for distinguishing these extremes, so the OCA index is of relative importance only when compared in time or space. However, variously constructed OCA indices are used quite often for this purpose.

As far as the Czech Republic is concerned, Cincibuch and Vávra (2000), for example, have followed the development of the OCA index in the past. The authors find a strong convergence of Czech OCA variables, especially to Germany, in the 1990s. At that time, according to their findings, the Czech Republic showed a higher degree of convergence than Greece or Portugal. A similar conclusion is reached, for example, by Skořepa (2013). Our findings confirm this trend for the period up to 2012. In the area of the TRADE indicator, however, the Czech Republic has been showing the best values of all analyzed economies on a long-term basis.

The OCA index may be a suitable indicator for assessing the preparedness of an economy to join a monetary union, however, it is not the only indicator. Other important criteria include, for example, labour mobility. For example, Selvaraj (2020) concludes that greater labour mobility, price and wage flexibility and fiscal integration are prerequisites for monetary union to enable a Member State to cope with asymmetric shocks and ensure economic stability. The Czech National Bank (2021) then takes into account other criteria when assessing the Czech Republic's preparedness to join the euro area. These are, for example, ownership links with the euro area, alignment of the financial cycle, convergence of interest rates with the euro area, alignment of the Czech koruna with the euro, alignment of financial markets, sustainability of public finances and convergence of euro area wealth levels. While ownership links with the euro area, convergence of interest rates vis-à-vis the euro area and the alignment of the Czech koruna with the euro are indicators that have spoken in recent years in favour of the Czech Republic's participation in the euro area; for the other mentioned indicators, they range from neutral to negative.

\section{Conclusion}

The OCA Index is a tool used to comprehensively assess the costs and benefits of a candidate for joining a monetary union. The OCA index is based on OCA theory and is constructed as a bilateral index assessing the appropriateness of introducing a single currency in two countries. The introduction of the single currency is all the more advantageous; the less the nominal exchange rate of countries tends to oscillate.

The degree of convergence of the Czech Republic in relation to Germany can be assessed as relatively good in comparison with the results of the OCA index values of other assessed economies. The position of the Czech Republic regarding the suitability of participation in EMU is comparable with other evaluated economies. In particular, the values of the TRADE indicator suggest a potentially high contribution of the monetary union created between the Czech Republic and Germany. However, the results of the SD indicator $(\Delta y \mathrm{y}-\Delta \mathrm{yj})$ evaluating the alignment of the economic cycle do not provide such a clear conclusion. Reserves can still be seen here in the Czech Republic, although in the last few years, after a period of considerable volatility, a favourable development can also be observed here. However, it is not yet clear how the effects of the Covid-19 pandemic will be reflected in the alignment of the Czech economy with the German economy and in the functioning of adjustment mechanisms.

The unconvincing value of the OCA index and the fact that the Czech Republic's preparedness to join the euro area needs to be assessed with regard to other factors such as the sustainability of public finances or convergence of euro area wealth levels, it can be stated that the degree of real convergence in the Czech Republic still does not reach the euro area average. Although the 
Czech Republic is approaching the euro area average in all key indicators, the gap remains significant in most indicators and continues to be a factor that speaks against the adoption of the euro in the coming years.

\section{Literature:}

1. Akalpler, E. Effective European monetary union in the light of the optimum currency area; model countries: Germany and Poland. Journal of Economic and Administrative Sciences. 2021, Vol. 37, No. 1, pp. 114-147. https://doi.org/10.1108/ JEAS-09-2019-0099

2. Baldwin, R., Wyplosz, C. The Economics of European Integration. London: McGraw-Hill, 2019. ISBN 9780077121631

3. Bayoumi, T., Eichengreen, B. Ever closer to heaven? An optimum-currency-area index for European countries. European Economic Review. 1997a, Vol. 41, Iss. 3-5. pp. 761-770.

4. Bayoumi, T., Eichengreen, B. Optimum currency areas and exchange rate volatility: Theory and evidence compared. In $\mathrm{B}$. Cohen (Ed.), International Trade and Finance: New Frontiers for Research (pp. 184-215). Cambridge: Cambridge University Press, 1997b. https://doi:10.1017/CBO9780511528392.008 5. Beine, M., Candelon, B., Hecq, A. Assessing a Perfect European Optimum Currency Area: A Common Cycles Approach. Empirica. 2000, Vol. 27, pp. 115-132. https://doi.org/10.1023/A:1026516026943

6. Cincibuch, M., Vávra, D. Na cestě $k$ EMU: Potřebujeme flexibilní ménový kurz? Finance a úvěr. 2000, 50, No. 6, pp. 361 -384. ISSN 2464-7683.

7. Corsetti, G. A Modern Reconsideration of the Theory of Optimal Currency Areas. European Economy - Economic Papers 2008 - 2015, Vol. 308, Directorate General Economic and Financial Affairs (DG ECFIN), European Commission, 2008.

8. Czech National Bank. Analýzy stupně ekonomické sladěnosti České republiky s eurozónou - 2020. Online. 2021. https://www.cnb.cz/cs/menova-politika/strategicke-

dokumenty/pristoupeni-k-eurozone/

9. DESTATIS. Economic and financial data for Germany. Online. 2021. https://www.destatis.de/EN/Themes/Economy/Sh ort-Term-Indicators/IMF/IMF_IWF.html

10. Frydrych, J. Teorie OCA ve vybraných odvětvích eurozóny a České republiky. Dissertation. Prague: Czech University of Life Sciences, Faculty of Economics and Management, 2018. 161 p.

11. Gabauer, D. Dynamic measures of asymmetric \& pairwise connectedness within an optimal currency area: Evidence from the ERM I systém. Journal of Multinational Financial Management. 2021 (in press). ISSN 1042-444X. https://doi.org/10.1016/j.mulfin.2021.100680

12. Horváth, R., Komárek, L. Teorie optimální měnových zón: rámec $k$ diskuzím o monetární integraci. Finance a úvěr. 2002, Vol. 52, No. 7-8, pp. 386-407. ISSN 2464-7683.

13. Horváth, R., Komárek, L. Optimum currency area indices: evidence from the 1990s. Working papers. Praque: IES FSV UK, 2003. 19 p.

14. Kenen, P. The Theory of Optimum Currency Areas: An Eclectic View. In: Mundell, R. and Swoboda, A., Eds., Monetary Problems of the International Economy, Chicago: The University of Chicago Press, 1969.

15. Mačí, J. Is There a Trend of Euroization of EU Countries Still Using Their National Currencies? Trade and Invoicing. E\&M Economics and Management. 2020, Vol. 23, Iss. 4, pp. 182-196. ISSN 2336-5064. https://doi.org/10.15240/tul/001/2 020-4-012

16. McKinnon, R. Optimum Currency Areas. The American Economic Review (American Economic Association). 1963, Vol. 53, No. 4, pp. 717-719.

17. Mongelli, F. European Economic and Monetary Integration, and the Optimum Currency Area Theory. 2008, No. 302, European Economy - Economic Papers 2008 - 2015, Directorate General Economic and Financial Affairs (DG ECFIN), European Commission.

18. Mundell, R. A Theory of Optimum Currency Areas. The American Economic Review (American Economic Association). 1961, Vol. 51, No. 4, pp. $661-663$.
19. Pilat, K. Optimum Currency Area Index for EU Countries beyond Eurozone. Ad Alta: Journal of Interdisciplinary Research. 2011, Vol. 1, Iss. 2, pp. 87-89. ISSN 1804-7890.

20. Selvaraj, S. The Significance of the Theory of Optimum Currency Areas in the Single Currency Zone - A Case Study of Germany and Greece. Journal of International Economics. 2020, Vol. 11, No. 1, pp. 2-14. ISSN 0022-1996.

21. Sideris, D. Optimum currency areas, structural changes and the endogeneity of the OCA criteria: evidence from six new EU member states. Applied Financial Economics, Taylor \& Francis Journals. 2011, Vol. 21, No. 4, pp. 195-206. https://doi.org/10.1 080/09603107.2010.528360

22. Skorrepa, M. Troubles in the Euro Area Periphery: The View through the Lens of a Simple Convergence Sensitive Optimum Currency Area Index. Finance a úvěr. 2013, Vol. 63, No. 2, pp. 129 - 151. ISSN 2464-7683

Primary Paper Section: A

Secondary Paper Section: $\mathrm{AH}$ 